\title{
Outline of an Uexküllian bio-ontology
}

\author{
Morten Tonnessen \\ Department of Philosophy, University of Oslo, \\ P.O.B. 1020 Blindern, N-0315 Oslo, Norway \\ e-mail: morten.tonnessen@hfstud.uio.no
}

\begin{abstract}
Traditionally, ontology, or at least western ontology, has been an anthropocentric enterprise, that takes only human experiences into account. In this paper I argue that a prolific biocentric ontology can be based on Uexküll's Umwelt theory. Uexküll offers the basis of an ontology according to which the study of experiences is a much wider field than it is as depicted by classical ontology and contemporary philosophy of consciousness. Based on the thoughts of the contemporary philosopher Thomas Nagel I claim that there might very well be lifeforms that are totally unimaginable to us. I argue that this view is compatible with the Umwelt theory, and that it should be adopted by biosemioticians. Furthermore, I argue that a biosemiotic possibilism should be implemented. Followingly, one should not claim to know which characteristics of living beings are universally and necessarily valid, but restrict oneself to statements about life as we know it.
\end{abstract}

If only people did not have to hear the eternal hyperbole of all hyperboles, the word World, World, World, when really each person should speak in all honesty only of Men, Men, Men.

Friedrich Nietzsche (1980: ix)

I will not, in this paper, give an account of Uexküll's views on space and time and specific sensory qualities. His theory on these subjects is properly dealt with in his own writings. Instead, I will make some remarks on the prospects and limits of Umwelt research. In this connection I will make use of some views held by the contemporary philosopher Thomas Nagel. 
But let me start making some general remarks on how Uexküll could influence philosophy. As for ethics, the Umwelt theory could, through its description of the uniqueness of any given Umwelt, provide a justification of the intrinsic value of all sensing beings. Animal ethics as well as ethical theories of biodiversity could be enriched by adopting the Umwelt theory. The Umwelt theory could even give birth to a brand new field within philosophy, which could be framed "the philosophy of experiences". The subject matter of this field would be all kinds of experiences that are present in the biosphere; questions concerning what an experience is and how they can be classified. The philosophy of experiences would differ from ontology in that its focus would be on the phenomenon of experiencing, not on what is experienced. Philosophy of consciousness, which deals only with conscious experiences, could be considered a special branch of this field.

\section{Bio-ontology}

I will use the notion bio-ontology for an ontology that takes not only human experiences into account, but non-human experiences as well. Bio-ontologists in general would probably claim that bio-ontology is the general field, whereas what is nowadays called "ontology" should in fact be considered to be a special branch of bio-ontology. Consequently, one could claim that what I call "bio-ontology" should really be called "ontology", whereas ontology that restricts itself to human experiences should be called "human ontology" or "anthropoontology".

It should be pointed out that the Uexküllian bio-ontology as I depict it is limited to sensory experiences. I have chosen this strategy - to give an outline of an ontology that is limited to sensory experiences - first of all because this is what is in line with Uexküll's biological approach. Furthermore because such an ontology will contain all the sensory qualities that we use to cloth our ideas and conceptions. So a purely sensory ontology might not be that poor, after all. 


\section{Uexküll and ontology}

Plato, Descartes and Kant can be regarded as the chief proponents of the anthropocentric paradigm within classical ontology. According to them, the phenomena that are experienced by human beings are the only phenomena that are worth paying attention to. It is in one sense a striking paradox that Uexküll considered himself a follower of Kant. It must be stressed that Uexküll was only Kantian in his subjectivist approach, not in his biocentric approach. His theory of experiences is, with its reach, substantially different from Kant's theory. He explicitly declares (in Uexküll 1928: 9) his departure from Kant's conception. The crucial difference between Kant and Uexküll is that Uexküll regards non-humans as subjects, as well as objects, of ontology, while Kant merely regards them as objects of ontology. Kant held that only rational beings, that is, subjects of cognition, are subjects of ontology, and that human beings are the only organisms that are rational beings. Uexküll, on the other hand, held that all sensing creatures (perhaps including plants - see Kull 2000) are subjects of ontology because they are autonomous entities that perceive and act. As a result, Uexküllian ontology will depict a world that is much richer in experiences, and, possibly, in qualities, than the Kantian ontology. If Uexküll's personal inclinations, or strategy for approval, had been different, he might just as well have called himself a critic of Kant.

Uexkülls Kantian postulate that all experience is relative to the subject implies that it does not make sense to talk about the qualities of an object without taking into account the subject that perceives the object. According to Uexküll, it is impossible to construct meaningful concepts about an objective world, that is, a world consisting only of objects. Such a world - consisting of Dinge an sich ${ }^{1}$ — is simply not possible to imagine. This does not necessarily imply that an objective world does not actually exist, but at least it implies that it cannot be perceived, or described in language. Followingly, the subject matter of an Uexküllian ontology is the subjective worlds ${ }^{2}$ of all sensing beings. The subject, rather than the object, is the starting point of ontology.

While traditionally the phenomenal world has been conceived of as one undivided world, with Uexküll, "the phenomenal world" only depicts the sum total of all the individual phenomenal worlds. He

\footnotetext{
${ }^{1}$ Things in themselves (Kant).

${ }^{2}$ Uexküll: "Subjektive Welten", "Erscheinungswelten", "Eigenwelten", "Umwelten".
} 
emphasizes that any given subject can only grasp, and indeed experience, a small part of the phenomenal world. Now, to what extent is it possible for a certain subject, say a scientist or a philosopher, to grasp the phenomena that do not appear in his own subjective world, but in an alien Umwelt?

\section{The privileged part in Umwelt research}

I find it useful to distinguish between a direct experience of phenomena and an indirect experience of phenomena. A direct experience of phenomena is what is present when the phenomenon in question is part of your own Umwelt. An indirect experience of phenomena takes place when you do not actually experience the phenomenon yourself, but only through a mediator, e.g. a concept or a model. I will argue that these two categories of experience are qualitatively different in all cases, even though, evidently, concepts can be more or less precise, and models can be more or less accurate. But even the most precise concept, and the most accurate model, is in a crucial sense completely different from the experience of the phenomenon itself (Uexküll 1910: 128). The qualities the scientist perceives are simply not the same as the qualities that the alien subject perceives. If the scientific concept or model is a good one, there will be a certain resemblance between the two, but they will never be identical. In this sense, the living being, the object of scientific inquiry, will always be the privileged part in Umwelt research, because it alone has direct access to the phenomenon.

To Uexküll, the statement that biology and other fields of scientific inquiry are human disciplines is non-trivial. A human discipline, in Uexküll's setting, is a discipline that is coloured and limited by the qualities of the human Umwelt. What biology reveals to us is the relationship between living beings and their related objects, not per se, but as they appear to human beings. Pobojewska (2001: 327) makes a similar point. However, one should keep in mind that the phenomenal sphere of science is much richer than the phenomenal sphere of any given human being (for a presentation of the idea of the Umwelten of species, see Uexküll 1928: 267). Its potential material includes all the functional cycles of all scientists. Consequently, a science aiming at widening its scope should recruit, or make use of, persons with abnormal abilities, such as savants. 


\section{The limits of Umwelt research}

Umwelt research is based on three important assumptions that concern the relationship between the organism and its Umwelt:

(1) The Umwelt of an organism - or, what sensory qualities an organism is capable of perceiving — is directly dependent on the constitution $^{3}$ of that organism.

(2) The Umwelt of an organism is just as complex as the constitution of that organism (Uexküll 1909: 249).

(3) The Umwelt of the observed organism differs just as much from our own Umwelt as the constitution of that organism differs from our own constitution (Uexküll 1909: 248; 1928: 105).

Followingly, the study of the constitution and environment of a specific organism can result in an outline of its Umwelt. Two kinds of Umwelten are particularly difficult to depict: Complex Umwelten and Umwelten that are substantially different from our own Umwelten. Since Uexküll considered the human Umwelt to be more complex than any animal Umwelt (Uexküll 1909: 248), he does not seem to have asked to what extent we can grasp non-human Umwelten that are as complex as or more complex than human Umwelten. This, on the other hand, is a question that is central to the contemporary philosopher Thomas Nagel ${ }^{4}$.

Thomas Nagel is, unlike Uexküll, a realist, but he acknowledges that "[t]he way the world is includes appearances, and there is no single point of view from which they can all be fully grasped" (Nagel 1986: 26). In What is it like to be a bat? he writes that "one might [...] believe that there are facts which could not ever be represented or comprehended by human beings, even if the species lasted forever simply because our structure does not permit us to operate with concepts of the requisite type" (Nagel 1993: 171). Nagel (1993: 166) claims that conscious experience is a widespread phenomenon, and that it occurs in countless forms "totally unimaginable" to us throughout the universe: "There is probably a great deal of life in the universe, and we may be in a position to identify only some of its forms, because we would simply be unable to read as behaviour the manifestations of creatures sufficiently unlike us" (Nagel 1986: 24). If Nagel is correct, the Umwelt scientist will have access only to a small

${ }^{3}$ Uexküll: "Bauplan", "Organisation".

4 Nagel has read Uexküll, but not referred to him (e-mail to the author, from February 19, 2001), and, consequently, does not use the notion "Umwelt". 
part of the existing Umwelten, and we will never be able to picture the real richness of the phenomenal world in an adequate way.

I would like to point out that Nagel's statement that there are lifeforms that are totally unimaginable to us might be valid even if one does not suppose that there is extra-terrestrial life. At least there are experiences that in one sense are totally unimaginable to us, e.g., experiences related to the sonar sense of bats. Even though we can get a certain impression of the sonar sense through studies of the bats constitution and behaviour, our concepts about it might be doomed to be vague. Nagel concludes that reflection on what it is like to be a bat seems to lead us to the belief "that there are facts that do not consist in the truth of propositions expressible in a human language". He holds that "[w]e can be compelled to recognize the existence of such facts without being able to state or comprehend them" (Nagel 1993: 171).

Now, is Nagel's view in accordance with Uexküll's Umwelt theory? Certainly it could be in accordance with the three basic assumptions that Uexküll sets forth concerning the relationship between the organism and its Umwelt. Nagel's view would imply that there are organisms that have constitutions that are so different from ours that their Umwelten are totally unimaginable to us. Uexküll himself does not, to my knowledge, make clear whether his assumptions are to hold for all life whatsoever, that is, whether they are to be regarded as universally valid. But let us assume that they are. Is the belief that there might be lifeforms totally unimaginable to us compatible with Umwelt theory? I think it is. At least, Uexküll does not explicitly state that there are no such lifeforms. But he does state that there are lifeforms of which our models will not be accurate.

According to Uexküll, the study of unicellular and other small organisms is relatively simple. The study of organisms with spaceand time-schemas, on the other hand, is a different matter. Our concepts about objects that such organisms relate to are necessarily vague $^{5}$. One reason for this is that the only material that is available to the scientist is the phenomena in his own Umwelt. Any object that he observes is coloured by his own impression of it. The impression that

${ }^{5}$ Uexküll 1910: 129: "Dann sind wir gezwungen, die Objekte, auf welche die Tiere mit Sicherheit reagieren, durch immer mehr und mehr vereinfachte Nachbildungen zu erfaßen [original: "erfeßen"], die in einfachster Weise die Bewegungen des Originals nachmachen". 
the organism itself has of its Umwelt is out of his reach ${ }^{6}$. All the Umwelt scientist can do, when he observes an organism, is to try to make clear which of the elements in his own Umwelt are also present in the Umwelt of that organism (Uexküll 1910: 128). And there seems to be a lot of elements in non-human Umwelten that are not present in human Umwelten (Uexküll 1928: 232-233). Now, what if there were two Umwelten, one of them belonging to a scientist and the other to an alien creature, that had no common elements? Then we would simply be unable to read as behaviour the manifestations of those creatures. Nagel would be right.

Unfortunately, neither the belief that there might be lifeforms that are totally unimaginable to us, nor the belief that there cannot in principle be any lifeforms that are unimaginable to us, are falsifiable. If lifeforms that are totally unimaginable to us do in fact exist, we will never know. And if they do not exist, we would not be able to discover it, nor would we be able to prove that they could not possibly exist.

\section{Consequences for biosemiotics}

In "Biosemiotics and formal ontology", Frederik Stjernfelt (1999) claims that certain characteristics of living beings are of universal validity. Even though I do find speculation about what characteristics of living beings, if any, are universal, interesting, I consider claims that certain characteristics are in fact universal to be unfounded, and impossible to justify. For practical purposes, however, one should presume that semiosis is a universal characteristic of living beings, because without semiosis, there can be no recognition.

Biosemioticians should adopt Nagel's view (Nagel 1986: 92) that "[a]bout some of what we cannot conceive we are able to speak vaguely $[. .$.$] but about some of it we may be unable to say anything at$ all, except that there might be such things". The puzzles that result from Nagel's view on creatures very unlike us call for a biosemiotic possibilism. A biosemiotic possibilism could be part of a progressive research programme, because it would not restrict biological inquiry to characteristics that we are already familiar with. Finally, rather than

${ }^{6}$ Uexküll 1910: 128: "Wir wissen, daß diese Umwelt ihr eigentümliches Gepräge durch uns selbst erhält. Das Gepräge, das das fremde Subjekt seiner Umwelt gibt, können wir niemals kennen lernen". 
claiming that the characteristics of living beings that we are familiar with, or some of them, are universal and necessary characteristics of life, we should simply state that these are the characteristics of life as we know it.

\section{References}

Kant, Immanuel 1975. Kritik der reinen Vernunft. Darmstadt: Wissenschaftliche Buchgesellschaft.

Kull, Kalevi 2000. An introduction to phytosemiotics: Semiotic botany and vegetative sign systems. Sign Systems Studies 28: 326-350.

Nagel, Thomas 1986. The View from Nowhere. Oxford: Oxford University Press.

- 1993. Mortal Questions. Cambridge: Cambridge University Press.

Nietzsche, Friedrich 1980. On the Advantage and Disadvantage of History for Life. Trans. Preuss, Peter. Indianapolis: Hackett Publishing Company.

Pobojewska, Aldona 2001. New biology — Jakob von Uexküll's Umweltlehre. Semiotica 134(1/4): 323-339.

Stjernfelt, Frederik 1999. Biosemiotics and formal ontology. Semiotica 127(1/4): $537-566$.

Uexküll, Jakob von 1909. Umwelt und Innenwelt der Tiere. Berlin: Verlag von Julius Springer.

- 1910. Über das Unsichtbare in der Natur. Österreichische Rundschau 25: 124-130. [Reprinted in Uexküll 1913: 55-66.]

- 1913. Bausteine zu einer biologischen Weltanschauung. München: F. Bruckmann A.-G.

- 1928. Theoretische Biologie. Berlin: Verlag von Julius Springer.

\section{Границы Юкскюлловской биоонтологии}

Традиционно онтология, по крайней мере на Западе, обладала антропоцентристским подходом, при котором учитывался только человеческий опыт. В данной статье доказывается, что продуктивная биоцентристская онтология может опираться на теорию Umwelt Юкскюлля. Юкскюлль предлагает исходные постулаты онтологии, согласно которым исследование опыта намного шире той сферы, которая описывалась до сих пор в классической онтологии и современной философии сознания. Основываясь на идеях современного философа Томаса Нагеля, автор статьи утверждает, что поо всей вероятности могут существовать формы жизни, которые мы неспособны даже представить. Доказывается, что это утверждение находится в соответствии с теорией Umwelt, и биосемиотики должны бы ее принять. Более того, эту биосемиотическую 
возможность стоило бы и применить. Следовательно, никто не должен утверждать, что знает, какие свойства живых организмов являются универсальными и необходимыми, а должен скорее ограничивать себя в своих утверждениях о жизни в том виде, в каком она нам известна.

\section{Uexkülli bio-ontoloogia piirjooni}

Traditsiooniliselt on ontoloogia, vähemalt läänes, olnud inimesekeskne lähenemine, mis võtab arvesse vaid inimkogemust. Käesolevas artiklis näitan ma, et viljakas biotsentristlik ontoloogia võiks põhineda Uexkülli omailma teoorial. Uexküll pakub ontoloogia lähtekohad, mille järgi kogemuse uurimine on märgatavalt laiem ala kui seda on kirjeldatud klassikalise ontoloogia ja kaasaegse teadvuse filosoofia poolt. Lähtudes tänapäeva filosoofi Thomas Nageli teostest, väidan, et vägagi tõenäoliselt võib olemas olla eluvorme, mis on meile täiesti kujutlematud. Ma näitan, et see vaade on kooskõlaline omailma teooriaga ning et biosemiootikud peaksid selle omaks võtma. Enamgi veel, arvan, et seda biosemiootilist võimalikkust tuleks ka rakendada. Järelikult ei tohiks keegi väita teadvat, millised elusorganismide omadused on universaalsete ja möödapääsmatutena üldkehtivad, vaid peaks pigem kitsendama oma formuleeringute kehtivuspiire elule säärasena nagu me seda tunneme. 